\title{
Prey or predator - expanding the food web role of sandeel Ammodytes marinus
}

\author{
Ole Ritzau Eigaard ${ }^{*, * *}$, Mikael van Deurs ${ }^{* *}$, Jane W. Behrens, Dorte Bekkevold, \\ Keith Brander, Marie Plambech, Kristian Schreiber Plet-Hansen, Henrik Mosegaard
}

National Institute of Aquatic Resources (DTU Aqua), Charlottenlund Castle, 2920 Charlottenlund, Denmark

\begin{abstract}
We report an unexpected observation of lesser sandeel Ammodytes marinus foraging on juveniles and late larval stages of the same species. This recording sheds new light on the cannibalistic and piscivorous capacity of forage fish and raises a number of questions about the role of forage fish in marine food webs. In 2012 and 2013, the stomachs of 748 sandeels from 36 different commercial sandeel hauls in the central North Sea were opened, and $9 \%$ of these contained late-stage sandeel larvae. In order to better understand the cannibalistic nature of sandeels, we made a detailed analysis of another 450 sandeels from a single haul with a high frequency of apparent cannibals. One-third of the stomachs contained a minimum of 1 young sandeel (mean length $2.7 \mathrm{~cm}$; max. length $4.9 \mathrm{~cm}$ ), $10 \%$ contained 5 or more, and 1 stomach contained 18 . Analyses of sample DNA confirmed that predator and prey were conspecifics. Larger specimens were more likely to be cannibals. Among cannibals, however, the specific sandeel larvae consumption was independent of cannibal size. We argue that this piscivorous cannibalistic behaviour may not only be a key factor in explaining recruitment fluctuations in North Sea sandeel stocks, but it may also add a new element to the complexity of energy flow in marine food chains.
\end{abstract}

KEY WORDS: Cannibalism · Energy flow $\cdot$ Forage fish · Food web · Piscivory $\cdot$ Population dynamics $\cdot$ Trophic control

\section{INTRODUCTION}

Forage fish transfer energy from plankton to larger predators in marine food webs (Pikitch et al. 2014). These planktivorous, fast-growing, small to mediumsized schooling forage fish species are vital to many larger marine predators, including mammals and sea birds (Thompson et al. 2007, Cury et al. 2011), and they also sustain a number of large commercial fisheries worldwide, accounting for more than $30 \%$ of global landings (Smith et al. 2011).

Most forage fish populations display large fluctuations in biomass on both decadal and inter-annual time scales (Pikitch et al. 2014). This has pronounced

${ }^{*}$ Corresponding author: ore@aqua.dtu.dk

** These authors contributed equally to this work ecological and socio-economic consequences and poses a challenge to sustainable fisheries management (Dickey-Collas et al. 2014). Several external drivers of these fluctuations have been identified, typically defined in relation to their impact points in the trophodynamic processes of the marine environment as either bottom-up, e.g. changing climate (Arnott \& Ruxton 2002) and cyclic changes in environmental conditions (Tourre et al. 2007), or topdown, i.e. predator-prey interactions at higher trophic levels (Frederiksen et al. 2007) and commercial fishing (Smith et al. 2011). Hence, the general perception is that forage fish abundance is controlled by food availability, physical-chemical conditions,

() The authors 2014. Open Access under Creative Commons by Attribution Licence. Use, distribution and reproduction are unrestricted. Authors and original publication must be credited. 
fishing mortality and predation pressure from higher trophic levels (Frank et al. 2007, van Deurs et al. 2009), and the prevailing biological trait being assigned to these species is that of prey to higher trophic levels and grazers on the secondary production.

Internal drivers of the so-called rollercoaster stock dynamics of forage fishes (Dickey-Collas et al. 2014) seem to be overlooked in the bottom-up versus topdown paradigm for investigating population dynamics and interactions in the marine ecosystem described above. Cannibalism is widespread among teleosts (Smith \& Reay 1991), and theory predicts that cannibalism in general can have profound effects on population structure and dynamics (Kohlmeier \& Ebenhöh 1995, Magnússon 1999); cannibalism could thus potentially be a hitherto overlooked co-driver of forage fish population dynamics. In support, sandeel cannibalism has been suggested by Lynam et al. (2013) as an explanation for the weak relationship between spawning stock biomass and recruitment in the North Sea sand eel stocks. However, reports of forage fish cannibalism are almost absent from the literature.

Here we report the unexpected finding of sandeel Ammodytes marinus cannibalizing large quantities of late larval stages and juveniles of their own species. These findings challenge the traditional perception of forage fish ecology and population dynamics by demonstrating that forage fishes are not only planktivorous, feeding on zooplankton (including fish eggs and small fish larvae; Macer 1966, Engelhard et al. 2014) but are also cannibals, feeding on relatively large conspecifics, i.e. juveniles and late stage larvae.

\section{MATERIALS AND METHODS}

\section{Sampling and stomach analyses}

In 2012 and 2013, the stomachs of 748 sandeels from 36 different commercial sandeel hauls (10 to 40 stomachs from each haul) in the central North Sea were opened. Of these, $9 \%$ contained at least 1 late stage sandeel larvae, and these were distributed over 17 hauls (between April 16 and June 7). In order to better understand the cannibalistic nature of individual sandeels, we made a detailed analysis of another 450 sandeel randomly sampled from a commercial haul (April 21, 2012) of the Danish industrial trawler 'L455 Lotte Vohnsen', taken from the primary Danish sandeel fishing grounds on Dogger Bank in the cen- tral North Sea $\left(54^{\circ} 8^{\prime} \mathrm{N}, 2^{\circ} 3^{\prime} \mathrm{E}\right)$. This haul had a relatively high prevalence of cannibals and was therefore suitable for analysing the predator to prey ratio and the allometry of the apparent cannibalistic behaviour. Total length of individual fish (from the tip of the snout to the tip of the longer lobe of the caudal fin) was measured to the nearest $\mathrm{cm}$ and weighed to nearest mg. Individual stomach contents of the sampled sandeel were subsequently sorted into 2 groups, fish larvae and non-fish larvae, and weighed. Individual fish larvae were counted and, if well enough preserved, the total length was also measured to the nearest $\mathrm{mm}$. Based on these data, we related predator size to cannibalism prevalence and size of the eaten conspecifics.

\section{Genetic analyses}

DNA sequence analysis (bar coding) was applied to determine prey species, using a standardized approach (Ratnasingham \& Hebert 2013). Total genomic DNA was extracted from 8 adult sandeel and 2 larval prey per gut (16 prey in total) using an Omega tissue DNA extraction kit (Omega Biotech). DNA concentrations were measured using a NanoDrop Fluorospectrometer (Thermo Fisher Scientific). Mitochondrial cytochrome $c$ oxidase subunit I (COI) gene PCR amplifications were undertaken using the primers FishF1 and FishR23 (Ward et al. 2005), amplifying a $\sim 650$ base pair fragment of the COI gene. PCR reactions included $0.5 \mu \mathrm{l}$ genomic DNA, $6.25 \mu \mathrm{l}$ Qiagen Multiplex PCR Master Mix (Qiagen) and $1.25 \mu \mathrm{l}$ of each $3.2 \mathrm{pmol}$ primer, with $4.5 \mu \mathrm{l}$ water bringing the total volume of the reaction to $12.5 \mu \mathrm{l}$. The PCR cycling regime was as follows: initial denaturation at $95^{\circ} \mathrm{C}$ for $15 \mathrm{~min}$ followed by 30 cycles of $94^{\circ} \mathrm{C}$ for $30 \mathrm{~s}, 57^{\circ} \mathrm{C}$ for $90 \mathrm{~s}$ and $72^{\circ} \mathrm{C}$ for $60 \mathrm{~s}$, and a final elongation for $15 \mathrm{~min}$ at $60^{\circ} \mathrm{C}$. PCR products were visualized under UV on an ethidium bromide-stained $2 \%$ agarose gel. Then $8 \mu$ samples of PCR products were cleaned using $1.2 \mu$ l phosphatase buffer, $0.3 \mu \mathrm{l}$ phosphatase enzyme, $0.3 \mu$ l Exonuclease I (Exo I) and $2.2 \mu \mathrm{l}$ water. Samples were incubated for $1 \mathrm{~h}$ at $37^{\circ} \mathrm{C}$ followed by $20 \mathrm{~min}$ at $80^{\circ} \mathrm{C}$. Sequencing reactions were performed using the BigDyeTerminator v3.1 Cycle Sequencing Kit (Applied Biosystems) with the forward primer. PCR conditions were $1 \mathrm{~min}$ at $96^{\circ} \mathrm{C}$, followed by 40 cycles of $10 \mathrm{~s}$ at $96^{\circ} \mathrm{C}, 5 \mathrm{~s}$ at $50^{\circ} \mathrm{C}$ and $4 \mathrm{~min}$ at $60^{\circ} \mathrm{C}$. PCR products were purified using $5 \mu \mathrm{l}$ EDTA, precipitated using $100 \%$ ethanol, and then dried, re-suspended in HighDye (Applied Biosystems) and sequenced using an ABI 3130 Genetic An- 
alyzer (Applied Biosystems). Sequence quality was checked by visual inspection, and specimens for which $>300$ base pairs high-quality sequence was obtained were matched against the BOLD data repository (Ratnasingham \& Hebert 2007).

\section{RESULTS}

\section{Stomach analysis}

The 450 sampled sandeels ranged from 10 to $17 \mathrm{~cm}$ $(12.2 \pm 1 \mathrm{~cm}$; mean $\pm \mathrm{SD})$ in total length. More than one-third (165) of the fish had 1 or more larval sandeels or juveniles in their stomach, 41 stomachs contained 5 or more, and the maximum number of ingested offspring was 18 (Fig. 1a). In total, 580 late stage larvae or juveniles were found in the 165 stomachs. In 98 of the stomachs containing offspring, 308 larvae or juveniles were well enough preserved to allow total length measurements $(2.7 \pm 0.6 \mathrm{~cm}$; mean $\pm \mathrm{SD}$ ) (Fig. 1b).

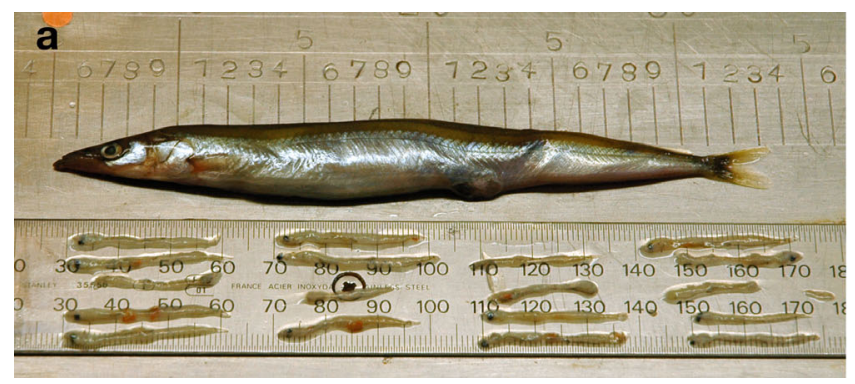

Larval sandeels co-occurred with copepods, amphipods and mysiids in the cannibal stomachs. Notably, however, sandeel larvae were often found clumped together in the stomachs rather than mixed up with the other gut content. This feeding pattern resulted in the presence of very distinct planktivory and piscivory diet bands in adult sandeel stomachs (Fig. 2a).

\section{Cannibalism allometry}

The number of sandeel larvae per stomach followed a zero-inflated distribution. Analyses based on size groups (1 cm intervals, and only size groups containing 10 or more sandeels) revealed a highly significant and clearly linear relationship between fish length and the proportion of fish being cannibals $(\mathrm{p}<$ 0.001, logistic regression: presence/absence vs. length, $\mathrm{df}=440$, cannibals were defined as fish with stomachs containing at least 1 sandeel larvae) (Fig. 3a). In contrast, the number of larvae consumed

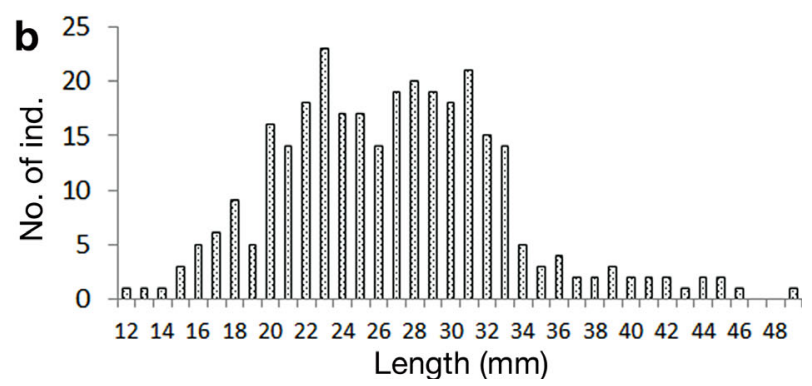

Fig. 1. (a) Ammodytes marinus $(14 \mathrm{~cm}$ ) with 18 late stage sandeel larvae found in a stomach sample. (b) Length frequency distribution of sandeel larvae and juveniles found in stomachs of adult sandeels $(n=308)$
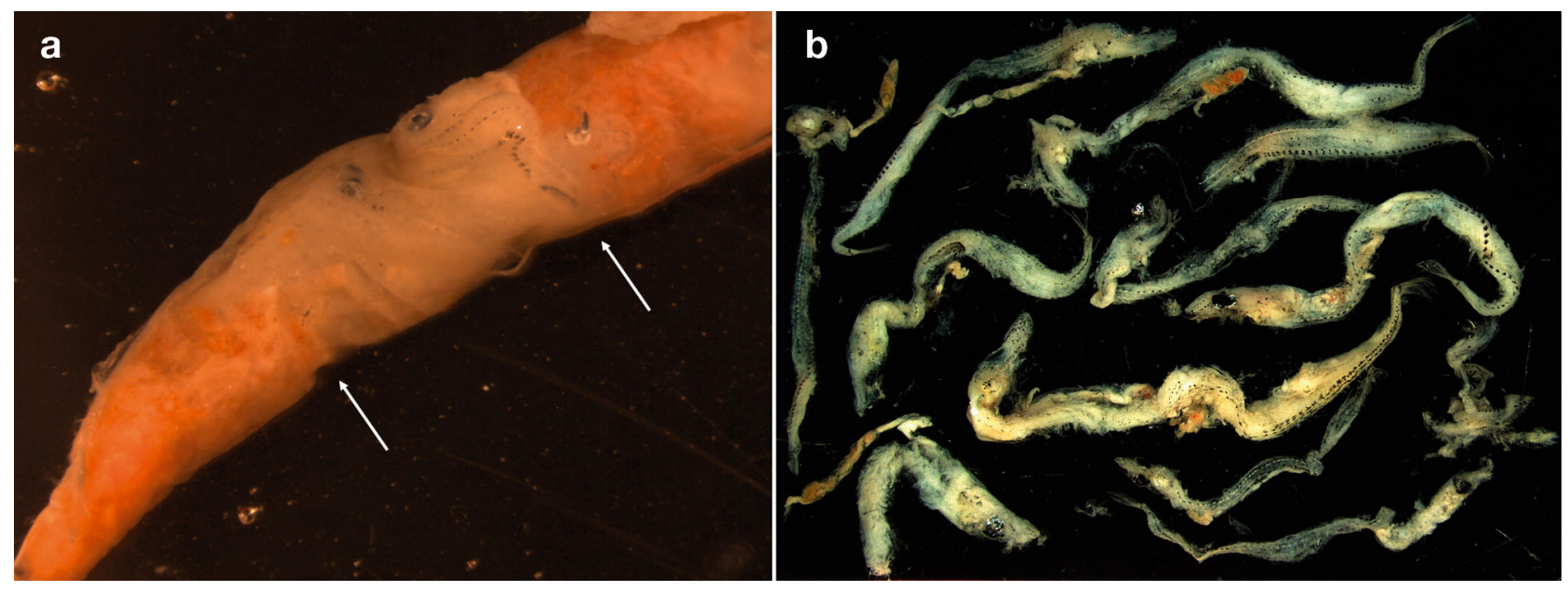

Fig. 2. (a) Sandeel Ammodytes marinus cannibal stomach with 3 distinct diet bands (copepods - sandeel larvae - copepods) marked by arrows. (b) Content of the middle diet band in (a) 
per gram cannibal (specific consumption) did not vary significantly between cannibal length groups $\left(\mathrm{p}=0.27\right.$, linear regression analysis, $\mathrm{r}^{2}=0.007, \mathrm{df}=$ 163) (Fig. 3b). The overall predator-prey length ratio was around 4:1, and the relationship between cannibal length and maximum length of ingested larvae was highly significant $(\mathrm{p}<0.001$, linear regression $y=3.13 x, r^{2}=0.98$, fitted to subset of data containing the largest $5 \%$ of larvae in each cannibal length group, df = 14) (Fig. 3c). However, there was only a weak, although significant, relationship between the mean length of ingested larvae and cannibal length $\left(\mathrm{p}=0.01\right.$, linear regression analysis, $\mathrm{r}^{2}=0.02, \mathrm{df}=$ 306).

\section{Genetics}

DNA concentrations varied among sampled fish. All analysed piscivores had DNA concentrations between 50 and $116 \mu \mathrm{g} \mu \mathrm{l}^{-1}$, whereas prey extractions generally had lower concentrations, between 1.7 and $108 \mu \mathrm{g} \mathrm{ll}^{-1}$. A total of 22 (8 predators; 14 prey; average 1.75 prey per predator) out of 24 individuals returned high-quality sequences for $>300$ base pairs and were subjected to barcoding analysis. In all cases, sequenced individuals were identified as Ammodytes marinus, demonstrating cannibalism. McCusker et al. (2013) found that COI-based barcoding is ineffective at distinguishing among W Atlantic Ammodytes species, presumably due to recent speciation. Likewise, in some cases, representatives of the Ammodytidae family in the NE Atlantic exhibited less than $1 \%$ divergence from their closest-related species in the BOLD database. However, in all cases, A. marinus alone came out with similarity $>99 \%$ (range 99.26 to $100 \%$; mean $99.82 \%$ ). Moreover, all individuals exhibited $>2 \%$ divergence from the next most similar species A. hexapterus, which is not reported from the area, and $>4 \%$ divergence from the next most similar species reported to occur in the area (Hyperoplus lanceolatus), suggesting that our species identification was accurate.

\section{DISCUSSION}

Here we report the unexpected finding of sandeel Ammodytes marinus cannibalizing large quantities of late larval stages and juveniles of their own species. Larger specimens were more likely to display cannibalistic behaviour, and as much as 18 late stage larvae/juveniles were found in a single stomach. We argue that this can only be the result of deliberate cannibalism. When conspecific larvae are part of the zooplankton and fall into the same predator-prey size ratio, which for sandeel and zooplankton lies between 1000:1 and 7000:1 (weight ratio, Ursin 1977, Christensen 2010), fish larvae cannibalism will inevitably occur. However, here we report a strikingly different predator-prey length ratio of roughly 4:1, corresponding to predator-prey weight ratios between 50:1 and 100:1 (using the length-weight relationship from van Deurs et al. 2013), indicating that lesser sandeel possess the capability to shift between planktivorous and piscivorous feeding. For comparison, the average predator-prey weight ratio for piscivorous cod is 150:1 (Ursin 1973), and the predator-
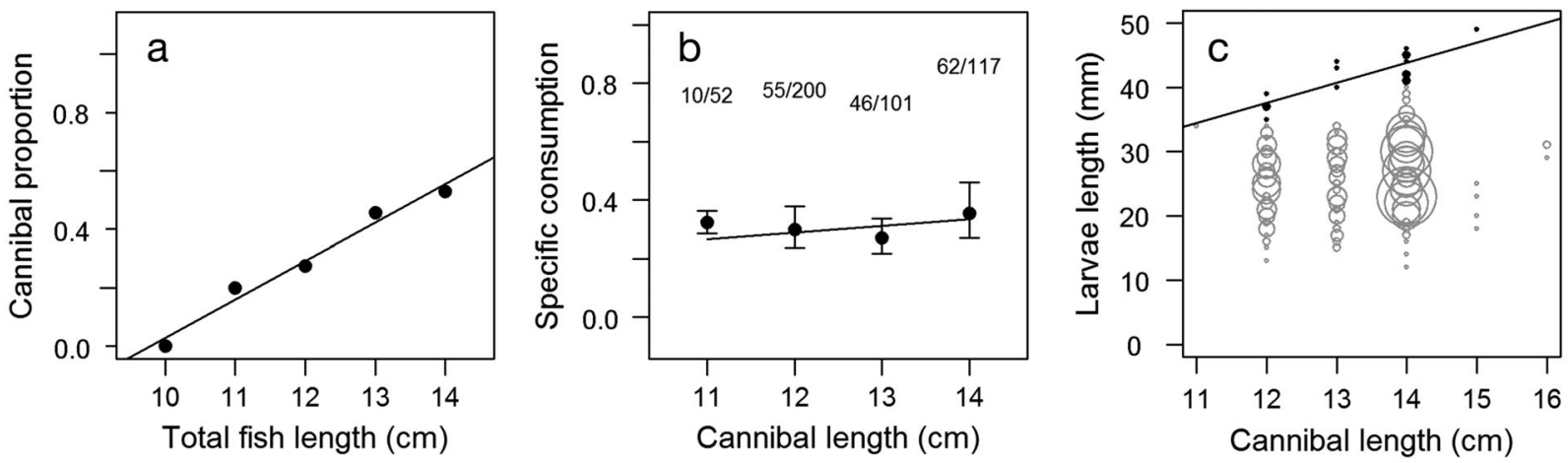

Fig. 3. Ammodytes marinus. (a) Proportion of sampled stomachs containing at least 1 larval sandeel (•) as a function of fish length. (b) Geometric mean number of larval sandeels per gram cannibal (•) as a function of cannibal length. Error bars represent 1 SD. Numbers above error bars are $\mathrm{n}^{\text {cannibals }} / \mathrm{n}^{\text {total }}$. (c) Prey size as a function of cannibal size and maximum larvae length as a function of cannibal size. The square root of the symbol radius is proportional to the number of observations (total $\mathrm{n}=$ 1936). The trend line is based on a linear regression $\left(y=3.13 x, r^{2}=0.98, p<0.001\right)$ fitted to the subset of data containing the largest $5 \%$ of larvae in each cannibal length group (filled symbols, $\mathrm{n}=24$ ) and represents the maximum larvae length ingested by each length group 
prey length ratio of cannibalistic gadoids lies in the range between 2:1 and 4:1 (Scharf et al. 2000, Juanes 2003). The notion that sandeels makes decisionbased shifts in foraging strategy when opportunities arise is supported by the distinct diet bands found in the adult sandeel stomachs, i.e. a temporary shift from copepod feeding to cannibalism had taken place (Fig. 2). Similar patterns of prey type shifts have been demonstrated for North Sea herring, where periods of fish egg dominance alternated with longer periods of crustacean feeding (Segers et al. 2007, Raab et al. 2012).

Our results strongly suggests that gape size limitation was not likely to have affected the observed allometry, as Fig. 3c indicates that the bulk of available larvae were smaller than the largest larvae approached by the smallest of the cannibals. This perception is in line with a number of studies arguing that other factors, such as behaviour, prey availability and predator capture efficiency, are equally as important as gape size in limiting maximum prey size (e.g. Juanes \& Conover 1994, Keeley \& Grant 1997 , Scharf et al. 2000).

Sandeel cannibalism has been suggested as a possible explanation for the weak relationship between spawning stock biomass and recruitment in sandeel (Lynam et al. 2013). The same causality has been hypothesized by Arnott \& Ruxton (2002) based on their documentation of a highly negative effect of age 1 sandeels on recruitment of age 0 sandeels. Our results strongly support these hypotheses by demonstrating that cannibalism of age 1+ sandeel on larvae and juveniles can be substantial in the North Sea.

Assuming that the spawning stock biomass consumes 0.2 sandeel per day per gram (as observed in the particular haul analysed in detail here), it will take less than a week for the sandeel stock in the North Sea to eat a quantity of late stage larvae in the same order of magnitude as the number of sandeel that settles into the stock in June/July (this crude upscaling exercise was based on mean recruitment numbers and spawning stock biomass for 1983 to 2010 from the ICES stock assessment working group for the North Sea demersal stocks, ICES 2014). This clearly highlights the cannibalistic potential of this species, but in a 'survival of the species' context such a mechanism is difficult to explain, and the rareness of the observations presented here also suggest that the average rate of sandeel cannibalism in the North Sea population is considerably lower. One explanation may be that limitations in temporal and spatial overlap between predator and prey with appropriate size ratios ensures the long-term survival of the stock, as observed for other fish species where cannibalism acts as a population regulator (Claessen et al. 2002).

The hypothesis that cannibalism is a rare event because spatio-temporal windows of overlap between sufficiently large adults and young ones are rare events fits the sandeel case well. Adult lesser sandeel feed between April and July. The eggs hatch around March, after which the bulk of the larvae disperse away from the sand banks, out of reach for the adult population that are behaviourally attached to the sand banks because of the innate need to bury at night. However, timing of egg hatching varies considerably; a study around the Shetland Islands found hatching time to vary from February to April (Wright \& Bailey 1996, Jensen et al. 2003). Hence, latehatched larvae are more likely to be consumed by older conspecifics until they have successfully drifted away from the sand banks. Late larvae and newly metamorphosed sandeel begin to show up in the catches around June, as they begin recruiting back to the areas inhabited by adult conspecifics. During this time, the adult population is about to start the overwintering period inactive in the sand, although age 1 individuals may display prolonged activity periods (Macer 1966, Kvist et al. 2001). Hence, the spatio-temporal window in which cannibalism is likely to affect population dynamics is limited to the period from April to July and further depends on the timing of hatching and the advection processes removing the hatched larvae from the sand banks.

Scarcity of alternative prey or dense aggregations of larvae or juveniles in the wrong place at the wrong time may induce cannibalistic behaviour, as has been demonstrated ex situ for copepods and anchovy (Brownell 1985). Low prey availability may also have been a key driver of the sandeel cannibalism demonstrated in this analysis. In 2012 and 2013 (sampling years), the Dogger Bank sandeel stock was at a particularly low level, which together with a number of other stock dynamic measures (e.g. poor recruitment and low fishing mortality) indicated poor ecological conditions (ICES 2014). Therefore, the observed cannibalism could be a response to this ecological situation and may not have been evident in years when preferred food supplies were adequate.

Although our findings represent a spatio-temporal snapshot, they highlight the fact that forage fish cannibalism has the potential to drive population dynamics. This potential may offer an additional explanation for the rollercoaster stock dynamics of many forage fishes (Dickey-Collas et al. 2014), which have traditionally been explained by predation mor- 
tality from higher trophic levels and variation in food availability (Frank et al. 2005, Ware \& Thomson 2005). Notably, our findings do not disqualify these 2 mechanisms as key drivers of the forage fish rollercoaster but strongly suggest that cannibalism and piscivory deserve a more prominent role in understanding forage fish stock fluctuations, as well as in the bottom-up and top-down paradigms currently dominating analyses of marine trophic cascading and ecosystem shifts (Fauchald 2010, Frank et al. 2011). Furthermore, forage fish cannibalism may also lead to energy recycling and thereby increased energy loss. This reduces trophic transfer efficiency (Fig. 4), which is an important ecological aspect of the food web and has been proposed as a major determinant of food-chain length (the energy-flow hypothesis) and predator production (Trussell et al. 2006).

Recordings of forage fish cannibalism and piscivory on larvae and juveniles are limited to a few observations of anchovies Engraulidae (Brownell 1985, Takasuka et al. 2007), which may be why this mechanism is vastly ignored in the general perception of forage fish stock dynamics and food web roles. The lack of field observations is, however, also somewhat surprising, considering that cannibalism is thought to be more common among teleosts than in any other animal phylum, due to a reproductive strategy where offspring quantity is favoured over offspring size, and a pelagic larvae phase is widespread. Currently, cannibalism has been recorded in more than 36 out of 410 teleost families (Smith \& Reay 1991). Two reasons spring to mind as to why forage fish cannibalism remains almost undocumented. Firstly, a general lack of awareness and dedicated investigations due to the conventional perception of forage fish as exerting only bottom-up control of larger predators (Fauchald et al. 2011, Pikitch et al. 2014), and secondly, practical difficulties with detecting larval prey, which is digested much faster than the conventional crustacean food (Christensen 2010). In summary, the observed sandeel feeding patterns highlight the need for targeted studies of the factors triggering shifts from planktivory to piscivorous cannibalism and incorporating these mechanisms into existing foraging models.

Acknowledgements. We thank the following people for contributing to this project: Bjarne Stage, Grete E. Dinesen, Eva M. Pedersen, Poul Tørring, J. W. Nielsen, and the crew and owners of 'L455 Lotte Vohnsen' and 'L526 Lonnie Hedvig'. This work was supported by the Ministry of Food, Agriculture and Fisheries of Denmark through the GUDP (Green Development and Demonstration Program).

\section{LITERATURE CITED}

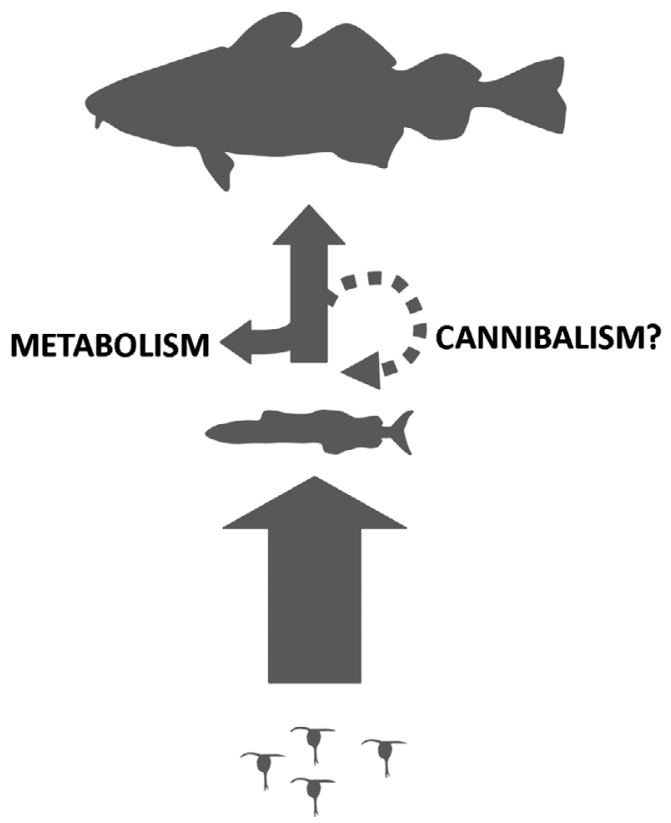

Fig. 4. Depiction of food chain energy transfer from secondary producers to top predators in the North Sea. The horizontal arrow pointing to the left illustrates how energy is lost for higher trophic levels due to metabolism of forage fish. The broken circular arrow illustrates the potential recycling of energy if cannibalism is the rule rather than the exception
Arnott SA, Ruxton GD (2002) Sandeel recruitment in the North Sea: demographic, climatic and trophic effects. Mar Ecol Prog Ser 238:199-210

> Brownell CL (1985) Laboratory analysis of cannibalism by larvae in the cape anchovy Engraulis capensis. Trans Am Fish Soc 114:512-518

> Christensen V (2010) Behaviour of sandeels feeding on herring larvae. The Open Fish Sci J 3:164-168

> Claessen D, Van Oss C, de Roos AM, Persson L (2002) The impact of size-dependent predation on population dynamics and individual life history. Ecology 83: 1660-1675

- Cury PM, Boyd IL, Bonhommeau S, Anker-Nilssen T and others (2011) Global seabird response to forage fish depletion-one-third for the birds. Science 334: 1703-1706

> Dickey-Collas M, Engelhard GH, Rindorf A, Raab K, and others (2014) Ecosystem-based management objectives for the North Sea: riding the forage fish rollercoaster. ICES J Mar Sci 71:128-142

> Engelhard GH, Peck MA, Rindorf A, Smout SC, and others (2014) Forage fish, their fisheries, and their predators: Who drives whom? ICES J Mar Sci 71:90-104

Fauchald P (2010) Predator-prey reversal: a possible mechanism for ecosystem hysteresis in the North Sea? Ecology 91:2191-2197

> Fauchald P, Skov H, Skern-Mauritzen M, Johns D, Tveraa T (2011) Wasp-waist interactions in the North Sea ecosystem. PLoS ONE 6:e22729 
Frank KT, Petrie B, Choi JS, Leggett WC (2005) Trophic cascades in a formerly cod dominated ecosystem. Science 308:1621-1623

Frank KT, Petrie B, Shackell NL (2007) The ups and downs of trophic control in continental shelf ecosystems. Trends Ecol Evol 22:236-242

Frank KT, Petrie B, Fisher JAD, Leggett WC (2011) Transient dynamics of an altered large marine ecosystem. Nature 477:86-89

Frederiksen M, Furness RW, Wanless S (2007) Regional variation in the role of bottom-up and top-down processes in controlling sandeel abundance in the North Sea. Mar Ecol Prog Ser 337:279-286

ICES (2014) Report of the Herring Assessment Working Group Area South of 62 N (HAWG), 12-21 March 2013, ICES Headquarters, Copenhagen. ICES CM 2013/ACOM:06

> Jensen H, Wright PJ, Munk P (2003) Vertical distribution of pre-settled sandeel (Ammodytes marinus) in the North Sea in relation to size and environmental variables. ICES J Mar Sci 60:1342-1351

Juanes F (2003) The allometry of cannibalism in piscivorous fishes. Can J Fish Aquat Sci 60:594-602

> Juanes F, Conover DO (1994) Piscivory and prey size selection in young-of-the-year bluefish: predator preference or size-dependent capture success? Mar Ecol Prog Ser 114:59-69

Keeley ER, Grant JWA (1997) Allometry of diet selectivity in juvenile Atlantic salmon (Salmo salar). Can J Fish Aquat Sci 54:1894-1902

Kohlmeier C, Ebenhöh W (1995) The stabilizing role of cannibalism in a predator-prey system. Bull Math Biol 57: 401-411

Kvist T, Gislason H, Thyregod P (2001) Sources of variation in the age composition of sandeel landings. ICES J Mar Sci 58:842-851

Lynam CP, Halliday NC, Höffle H, Wright PJ, van Damme CJG, Edwards M, Pitois SG (2013) Spatial patterns and trends in abundance of larval sand eels in the North Sea: 1950-2005. ICES J Mar Sci 70:540-553

Macer CT (1966) Sand eels (Ammodytidae) in the southwestern North Sea: their biology and fishery. Ministry of Agriculture, Fisheries and Food: Fishery Investigations, Series 2, Vol 24, No. 6. HM Stationary Office, London

Magnússon KG (1999) Destabilizing effect of cannibalism on a structured predator-prey system. Math Biosci 155:61-75

> McCusker MR, Denti D, Van Guelpen L, Kenchington E, Bentzen P (2013) Barcoding Atlantic Canada's commonly encountered marine fishes. Mol Ecol Resour 13:177-188

Pikitch EK, Rountos KJ, Essington TE, Santora C, and others (2014) The global contribution of forage fish to marine fisheries and ecosystems. Fish Fish 15:43-64

Raab K, Nagelkerke LAJ, Boerée C, Rijnsdorp AD, Temming A, Dickey-Collas M (2012) Dietary overlap between the

Editorial responsibility: Kenneth Sherman, Narragansett, Rhode Island, USA potential competitors herring, sprat and anchovy in the North Sea. Mar Ecol Prog Ser 470:101-111

Ratnasingham S, Hebert PDN (2007) BOLD: the Barcode of Life Data System (http://www.barcodinglife.org). Mol Ecol Notes 7:355-364

Ratnasingham S, Hebert PDN (2013) A DNA-based registry for all animal species: the Barcode Index Number (BIN) system. PLoS ONE 8:e66213

> Scharf FS, Juanes F, Rountree RA (2000) Predator size-prey size relationships of marine fish predators: interspecific variation and effects of ontogeny and body size on trophic-niche breadth. Mar Ecol Prog Ser 208:229-248

Segers FHID, Dickey-Collas M, Rijnsdorp AD (2007) Prey selection by North Sea herring (Clupea harengus), with special reference to fish eggs. ICES J Mar Sci 64:60-68

Smith C, Reay P (1991) Cannibalism in teleost fish. Rev Fish Biol Fish 1:41-64

Smith ADM, Brown CJ, Bulman CM, Fulton EA, and others (2011) Impacts of fishing low-trophic level species on marine ecosystems. Science 333:1147-1150

Takasuka A, Aoki I, Oozeki Y (2007) Predator-specific growth-selective predation on larval Japanese anchovy Engraulis japonicus. Mar Ecol Prog Ser 350:99-107

Thompson P, Ingram S, Lonergan M, Northridge S, Hall A, Wilson B (2007) Climate change causing starvation in harbour porpoises? Biol Lett 3:533-534

Tourre YM, Lluch-Cota SE, White WB (2007) Global multidecadal ocean climate and small-pelagic fish population. Environ Res Lett 2:034005

Trussell GC, Ewanchuk PJ, Matassa CM (2006) The fear of being eaten reduces energy transfer in a simple food chain. Ecology 87:2979-2984

Ursin E (1973) On the prey size preferences of cod and dab. Medd Dan Fisk Havunders NY Ser 7:85-98

Ursin E (1977) Multispecies fish stock assessment for the North Sea. ICES CM 1977/F: 42

van Deurs M, van Hal R, Tomczak MT, Jónasdóttir SH, Dolmer P (2009) Recruitment of lesser sandeel Ammodytes marinus in relation to density dependence and zooplankton composition. Mar Ecol Prog Ser 381:249-258

van Deurs M, Christensen A, Rindorf A (2013) Patchy zooplankton grazing and high energy conversion efficiency: ecological implications of sandeel behavior and strategy. Mar Ecol Prog Ser 487:123-133

> Ward RD, Zemlak TS, Innes BH, Last PR, Hebert PDN (2005) DNA barcoding Australia's fish species. Philos Trans R Soc Lond B Biol Sci 360:1847-1857

- Ware DM, Thomson RE (2005) Bottom-up ecosystem trophic dynamics determine fish production in the northeast pacific. Science 308:1280-1284

> Wright PJ, Bailey MC (1996) Timing of hatching in Ammodytes marinus from Shetland waters and its significance to early growth and survivorship. Mar Biol 126:143-152

Submitted: July 8, 2014; Accepted: September 30, 2014 Proofs received from author(s): November 21, 2014 